Yapılandırmacı Yaklaşım Kavramına İlişkin Sınıf Öğretmeni Adaylarının Görüşlerinin Metaforlar Aracılığı İle İncelenmesi *

\title{
Hanifi ŞEKERCI**
}

Öz: Türkiye’de 2005 yılından beri öğretim programları yapılandırmacı yaklaşıma göre oluşturulmaya çalışılmaktadır. Bu bakımdan öğretmen adayları lisans eğitimleri boyunca yapılandırmacı yaklaşıma ilişsin pek çok bilgi ve deneyim kazanmaktadır. Sınıf öğretmeni adaylarının yapılandırmacı yaklaşım kavramı ile ilgili algı ve görüşlerinin belirlenmesinin, onların lisans öğrenim sürecine ve öğretim programlarının onlar tarafindan nasıl uygulanabileceğine ilişkin önemli bakış açıları ortaya koyacaktır. Bu bakımdan araştırmada sınıf öğretmeni adaylarının yapılandırmacı yaklaşım kavramına ilişkin algı ve görüşleri metaforlar aracılığıyla incelenmeye çalışılmıştır. Çalışma, nitel araştırma yöntemi desenlerinden olgu bilime göre tasarlanmıştır. Araştırmanın çalışma grubunun seçiminde, amaçlı örneklem tekniklerinden ölçüt örneklem kullanılmıştır. Araştırmaya 117 sınıf öğretmeni adayı katılmıştır. Çalışmada veri toplama aracı olarak "Yapılandırmacı yaklaşım gibidir. Çünkü .” ifadesinin yer aldığı form kullanılmıştır. Verilerin analizinde içerik analizi tekniğinden yararlanılmıştır. Araştırmada elde edilen bulgulara göre sınıf öğretmeni adayları yapılandırmacı yaklaşım kavramı ile ilgili 80 adet geçerli metafor üretmiştir. Bu metaforlar özelliklerine göre 10 kavramsal kategori altında toplanmıştır. Bunun yanında yapılandırmacı yaklaşım kavramı ile ilgili en fazla üretilen metaforların "hayat" ve "yaşamın kendisi” olduğu tespit edilmiştir. Sınıf öğretmeni adayları tarafindan üretilen metaforların en fazla sınıflandırıldığı kategoriler ise "öğrenciyi aktif kılma” ve "anlamlı bilgi oluşturma” olmuştur.

Anahtar Kelimeler: Yapılandırmacı yaklaşım, metafor, sınıf öğretmeni adayları.

\footnotetext{
*Bu araştırma için Dicle Üniversitesi Sosyal ve Beşeri Bilimleri Etik Kurulu Başkanlığında (28/04/2020 tarih ve 43939 sayısı) etik izin alınmıştır.

**Arş. Gör. Dr. Dicle Üniversitesi, Eğitim Fakültesi, Temel Eğitim Bölümü, Email: hnfskrc@gmail.com, Orcid No: 00000002-1280-3228
} 


\section{Examining the Prospective Primary School Teachers' Views on The Concept of Constructivist Approach Through Methapors}

Abstract Education programs since 2005 in Turkey are aimed to develop according to the constructivist approach. In this regard, pre-service teachers gain a lot of knowledge and experience regarding the constructivist approach during their undergraduate education. Determining the perceptions and opinions of primary teacher candidates about the concept of constructivist approach will reveal important perspectives on their undergraduate education process and how the curriculum can be implemented by them. In this respect, the perceptions and views of primary teacher candidates about the concept of constructivist approach in the research were tried to be examined through metaphors. The research was designed according to phenomenology, one of the qualitative research methods. Criterion sampling from purposeful sampling techniques was used in the selection of the working group of the research. 117 primary teacher candidates participated in the research. As a data collection tool in the study, the form "Constructivist approach is like Because "was used. Content analysis technique was used in the analysis of the data. According to the findings obtained in the research, primary teacher candidates produced 80 valid metaphors about the concept of constructivist approach. These metaphors were grouped under 10 conceptual categories according to their characteristics. In addition, it has been determined that the most frequently produced metaphors related to the concept of constructivist approach are "life" and "life itself". The categories in which the metaphors produced by the primary teacher candidates were classified the most were "activating the student" and "creating meaningful knowledge".

Keywords: Constructivist approach, metaphor, prospective primary school teachers.

\section{Giriş}

Bilgi felsefesi ve öğrenme anlayışı olarak ele alınabilecek bir kavram olan yapılandırmacılığın kökeni ilk çağ filozoflarına kadar dayandırılabilmektedir. İlk çă̆ filozoflarından Sokrates'in "bilgi sadece algıdır" düşüncesi onu ilk yapılandırmacı olarak değerlendirmemizi olanaklı kılmaktadır. Tynjälä (1999) ile Duffy ve Cunningham (1996) yapılandırmacılıkta Kant felsefesinin izlerinin bulunduğunu belirtmektedir. Nitekim Kant'a göre bireyler bilgiyi aktif olarak alıp, önceden özümlediklerini yeni bilgiye bağlayarak kendi yorumu haline getirmektedir. Haney ve McArtur (2002) ile Yager (1991) ise 
yapılandırmacılığın öğrenme felsefesi olarak temellerini 18. yüzyıl düşünürlerinden Vico’ya dayandırmaktadır. Her ne kadar Thomas Khun ve William James gibi düşünürlerin görüşlerinde yapılandırmacılığın izlerine rastlansa da John Dewey, Jean Piaget ve L.S. Vygotsky gibi eğitim kuramcılarının çalışmalarıyla yapılandırmacılık günümüzdeki yapısına ulaşmıştır (Delil ve Güleş, 2007, Fer ve Cırık, 2007, Fox, 2001, Von Glasersfeld, 1995). Yapılandırmacılık birçok düşünür ve eğitim kuramcısının görüşlerinden ve çalışmalarından hareketle bilginin doğası hakkında açıklamalar yapan bir bilgi kuramı olarak ele alınabileceği gibi (Açıkgöz, 2003; Airasian ve Walsh, 1997; Brooks ve Brooks, 1993; Duman, 2004; Tezci, 2002) bir öğrenme teorisi olarak da değerlendirilebilmektedir (Savery ve Duffy, 1995).

Tarihsel ve felsefi kökenleri yukarıda ele alınan yapılandırmacı yaklaşımın son dönemde eğitim bilimleri alan yazınında oldukça tartışılan bir kavram olduğu görülmektedir. $\mathrm{Bu}$ durumun nedeni yapılandırmacılığın bilginin edinilmesini, öğrenme ve öğretme süreçlerini nesnelci anlayış ve geleneksel yaklaşımdan farklı olarak ele almasından kaynaklanmaktadır (Albayrak, 2012 Özden, 2010). Nesnelci ve davranışçı yaklaşıma göre öğrenenden bağımsız olarak dış dünyada var olan nesnel bilgiler, bireylere anlatım yöntemi ve uygun pekiştireçler kullanılarak aktarılabilir. Öğrenen de bu bilgileri zihnine yerleştirdiğinde veya ezberlediğinde öğrenme gerçekleşmektedir. Yapılandırmacı yaklaşım davranışçılığa göre öğrenmeye farklı bir bakış açısı getirmiştir. Tezci ve Gürol (2003) yapılandırmacı yaklaşımda bilginin öğrenenden bağımsız olmadığını ifade etmektedir. Çevresi ile etkileşime geçen birey dış dünyadan aldığı bilgileri önceki bilgileri, deneyimleri ve tutumlarına göre anlamlandırarak öznel bilgi oluşturmaktadır. Diğer bir ifadeyle yapılandırmacılığa göre öğrenme, yeni karşılaşılan bilgiler önceki bilgilerle ilişkilendirilerek veya bilinen konulara bağlanarak gerçekleşmektedir (Sherman, Barbara ve Kurshan, 2005). Bu öğrenme sürecinde birey yeni öğrendiği bilgileri önce mevcut bilişsel şemalarına yerleştirmeye yani özümlemeye çalışır. Ancak yeni bilgiler mevcut şemalar ile tutarsızlık gösterdiğinde ya da mevcut bilişsel şemalar yeni bilgileri özümleme noktasında yetersiz kaldığında yeniden biçimlendirilmektedir (Senemoğlu, 2005, 37). Her kişinin bilgi ve deneyimi farklılık arz ettiğinden, öğrenilenlere ilişkin oluşan şemalar ve bilgi de bireyseldir. Erdamar Koç ve Demirel (2008)'e göre yapılandırmacılığın bilgiye ve öğrenmeye olan bakış açısı, davranış̧̧ı kuramın etkisindeki geleneksel eğitim programlarının değişikliğe uğramasına yol açmıştır. Bu durum öğretmen ve öğrencinin rollerinde, derslerin içeriğinde, öğretim yöntemlerinde, kullanılan araç ve gereçlerle ölçme ve değerlendirme yöntemlerinde önemli farklılıkların gerçekleşmesine neden olmuştur. Eğitim bilimleri alan yazınında yapılandırmacılığın tartışılmasının önemli nedenlerinden biri bu durumdur. $\mathrm{Bu}$ 
bağlamda yapılandırmacı yaklaşımda öğretmen ve öğrenci rollerine değinme, öğrenme ortamlarının tasarımını tartışma ve değerlendirme yöntemlerini ele almak yararlı olacaktır.

Yapılandırmacı yaklaşım davranışçı yaklaşımdaki öğretmen rolünü farklılaştırmaktadır. Davranışç1lıktaki hiyerarşik öğretmen öğrenci ilişkisi yapılandırmacı yaklaşımda yoktur, öğretmen teorik bilginin kaynağı olarak hareket etmemekte, öğrencilere bilgiye ulaşmada rehber rolü üstlenmekte (Tezci ve Gürol, 2003), öğrenme aktivitelerini seçmekte, problem durumları oluşturarak öğrencilerin yaratıcı çözümler ortaya koymalarını sağlamakta (Beevevino, Dengel ve Adams 1999; 276), öğrencilerin merak ve ilgisini arttırıcı sorular sormakta, soru sormalarını desteklemekte, üst düzey düşünme becerilerini geliştirecek görevler oluşturmakta, benzetme yapma ve ilişki kurmaları için zaman onlara zaman vermektedir (Brooks ve Brooks, 1999).

Yapılandırmacı yaklaşımın öğretmene yüklediği sorumluluk ve rollerden de anlaşılacağı üzere öğrencilerin de öğrenme sürecinde bir takım sorumlulukları ve rolleri vardır. Yapılandırmacı yaklaşımda öğrenci kendi öğrenmesinden sorumludur ve öğrenme sürecinde aktiftir. Bu öğrenme sürecinde öğrenci kendine sunulan bilgiyi olduğu gibi kabul edip almak yerine öğretmenin kendisi için oluşturduğu öğrenme firsatlarından üst seviyede yararlanmaya çalışır (Yaşar, 1998); eleştirel ve yapıcı sorular sorar, diğer öğrencilerle ve öğretmenle iletişim kurarak fikirleri tartışır (Demirel, 2008: 22). Böylece hem kendinin hem de sınıfındaki diğer arkadaşlarının gelişimine katkı sağlar. Yapılandırmacı öğrenme sürecinde öğrenciler bilgiyi araştırarak, keşfederek, yorumlayarak, çevreyle etkileşimde bulunarak ve yaratarak oluşturmaktır. $\mathrm{Bu}$ bakımdan öğrencilerin meraklı, girişimci, sabırlı ve sebatkar olmaları gerekmektedir.

Yapılandırmacı yaklaşımın öğretmen ve öğrenciye yüklediği sorumluluklar öğrenme ortamlarının tasarımını da etkilemektedir. Buna göre öğrencilerin kendi öğrenmelerinin sorumluluğunu alması, sosyal etkileşimde bulunması, çoklu ortamların kullanımı ve otantik görevlerle (öğrencilerin yakın çevrelerindeki gerçek yaşam problemlerinin çözümü için oluşturulan görevler) öğrencilerin karşılaştırılması yapılandırmacı öğrenme ortamının tasarlanmasında dikkate alınmalıdır (Honebein, 1996; Özden, 2010; Paavola ve Lakkala, 2004). Otantik görevlerin gerçek yaşamla ilişkili olması, tam olarak tanımlanmaması ve karmaşık olması, farklı bakış açılarını ve işbirliğini gerektirmesi önemlidir (Demirhan ve Demirel, 2002; Reeves, Herrington ve Oliver 2002; Yaşar, 1998). Öğrencilerin öğrenme sürecinde aktif olduğu işbirliğine dayalı öğrenme, proje tabanlı öğrenme, probleme dayalı, beyin firtınası vb. yöntem ve tekniklerin öğrenme ortamında kullanması gerekmektedir. Ayrıca öğrenme ortamlarında 
öğrencilerin fikirlerini rahatça ifade ettiği, özgürlükçü ve demokratik bir sınıf ikliminin oluşturulması önemlidir.

Yapılandırmacı yaklaşımda öğrenme sürecinin değerlendirilmesi önemli görülmektedir. Bundan dolayı öğrencilerin ortaya koyduğu gelişim öğrenme süreci boyunca farklı araçlarla değerlendirilmeye çalışılmaktadır ve değerlendirme etkinlikleri öğrenme sürecinin bir parçasıdır (Tezci ve Gürol, 2003). Bu kapsamda öğrenci ürün dosyaları, öz değerlendirme ve akran değerlendirme formları, dereceli puanlama anahtarları gibi alternatif ölçme ve değerlendirme araçlarıyla öğrencilerin öğrenme süreci boyunca gösterdikleri gelişim değerlendirilmeye çalışılmaktadır.

Araştırmada sınıf öğretmeni adaylarının yapılandırmacı yaklaşıma ilişskin algı ve görüşleri metaforlar aracılığıyla araştırılmaya çalışıldığından, metafor kavramının tanımlanmasının ve yapılandırmacılıkla ilişkisinin tartışılmasının yararlı olacağı düşünülmektedir. Metaforu Lakoff ve Johanson (2005) bir şeyi (olgu, kavram, nesne gibi) başka bir şeye göre anlamak ve tecrübe etmek, Cerit (2008) farklı benzetmeler kullanarak hayatı, çevreyi, olayları ve nesneleri açıklamaya çalışırken kullanılan araçlar olarak tanımlamaktadır. Saban, Koçbekir ve Saban’a (2006) göre ise metafor üst düzey soyut ve karmaşık veya kuramsal olguları anlamada ve açıklamada kullanılan zihinsel vasıtalardır. Bu bakımdan metaforların karmaşık kavram, olay veya durumları anlamlandırma ve açıklamada kullanılan bilişsel nitelikli araçlar olduğu söylenebilir. Semerci (2007) ise metaforlarla yapılandırmacılık arasında güçlü bir ilişkinin olduğunu ifade etmektedir. Çünkü yeni bir metaforun kavram sistemine girmesi, eski bilgiler ile kavramlar sisteminin yeniden düzenlenmesine yol açmaktadır. Bu bakımdan yeni bilgilerin edinilmesinde ve bu bilgilerin düzenlenmesinde metaforlar oldukça etkili olabilmektedir. Metaforların zihindeki bilgi düzenleme süreçlerindeki bu rolü ile yapılandırmacılığın bir bilgi felsefesi ve öğrenme teorisi olması iki kavram arasındaki ilişkinin varlığını ortaya koymaktadır.

$\mathrm{Bu}$ araştırmada sınıf öğretmeni adaylarının yapılandırmacı yaklaşıma ilişkin görüşleri metaforlar aracılığıyla belirlenmeye çalışılmıştır. İlgili yabancı alan yazında sınıf öğretmenlerinin yapılandırmacı yaklaşım ile etik inançları arasındaki ilişki (Sharkey ve Gash, 2020), yapılandırmacı eğitime ilişkin coğrafya öğretmenlerinin görüşleri (Yang, Chang ve Hsu, 2008), beden eğitimi öğretmen adaylarının oyun öğretimine (Wang ve Ha, 2012), yabancı dil öğretmenlerinin kültür öğretimine (Sercu, Garcia ve Prieto, 2005) dair görüşleri yapılandırmacı yaklaşım perspektifiyle araştırılmıştır. Yerli alan yazın incelendiğinde ise sınıf öğretmenlerinin (Karadağ, Deniz, Korkmaz ve Deniz, 2008; Özdemir ve Kıroğlu, 2011; Özenç ve Doğan, 2012; 
Saydam, 2009), sınıf öğretmeni adaylarının (Çaycı ve Altunkeser, 2015; İnel, Evrekli ve Türkmen, 2010) sosyal bilgiler öğretmen adaylarının (Geçit, 2015) ve fen bilgisi öğretmen adaylarının (Evrekli, İnel, Balım ve Kesercioğlu, 2009) yapılandırmacı yaklaşım ile ilgili tutumlarının, görüşlerinin, bilgi düzeylerinin ve yeterliliklerinin incelendiği çalışmalara rastlanmıştır. Ayrıca eğitim fakültelerinde görev yapan akademisyenlerin yapılandırmacı eğitim kavramına (Günay ve Yücel Toy, 2015), yapılandırmacı öğretmen kavramına (Günay, 2015) ve öğretmenlerin yapılandırmacı öğretmen kavramına (Eminoğlu Küçüktepe ve Gürültülü, 2014) ilişkin algılarının metaforlar aracılığı ile incelendiği çalışmalar da saptanmıştır. Ancak sınıf öğretmeni adaylarının yapılandırmacı yaklaşım kavramına ilişkin sahip oldukları algıların metaforlar aracılığıyla tespit edildiği bir çalışmaya rastlanmamıştır. Bu bakımdan sınıf öğretmeni adaylarının yapılandırmacı yaklaşıma ilişkin algı ve görüşlerinin metaforlar aracılığıyla ortaya konulmasının ilgili literatürdeki eksikliği kapatacağı düşünülmektedir. Araştırmanın sınıf öğretmeni adaylarıyla sınırlı tutulmasının nedeni, branş faktörünün yapılandırmacı yaklaşım kavramına ilişkin öğretmen adaylarının algılarının şekillenmesinde etkili olabileceği düşüncesidir. Çünkü eğitim bilimleri dersleri her ne kadar birbirine benzer içerikte olsa da, alan eğitimi ile ilgili özel öğretim derslerinin öğretmen adaylarının yapılandırmacı yaklaşım kavramına ilişkin algılarını farklılaştırabilir. Bundan dolayı araştırmada sadece sınıf öğretmeni adaylarının yapılandırmacı yaklaşım kavramına dair algıları belirlenmeye çalışılmıştır. Sınıf öğretmeni adaylarının aldıkları eğitim sürecinde edindikleri bilgi ve deneyimlerin yapılandırmacı yaklaşım kavramına ilişkin algı ve düşüncelerini nasıl etkilediğinin saptanmasıyla sınıf eğitimi alanındaki paydaşlara fikir ve bakış açısı kazandırılabileceği düşünülmektedir. Bu anlamda araştırmanın amacı sınıf öğretmeni adaylarının yapılandırmacı yaklaşım ile ilgili görüşlerini metaforlar aracılığı ile tespit etmektir. $\mathrm{Bu}$ amaç doğrultusunda aşağıdaki sorulara yanıt aranmaktadır:

- Sınıf öğretmeni adayları "yapılandırmacı yaklaşım” kavramına ilişkin sahip oldukları algılarını hangi metaforlar aracılığı ile açıklamaktadır?

- "Yapılandırmacı yaklaşım” kavramına ilişkin olarak sınıf öğretmeni adayları tarafından ifade edilen metaforlar, ortak özellikler yönünden hangi kategoriler altında toplanmaktadir?

\section{Yöntem}

\section{Araştırmanın Deseni}


$\mathrm{Bu}$ çalışma nitel araştırma yöntemi desenlerinden olgu bilime göre tasarlanmıştır. Yıldırım ve Şimşek (2011: 72) olgu bilimde farkında olunan ancak derinlemesine ve ayrıntılı bir anlayışa sahip olunmayan olgulara odaklanıldığını belirtmektedir. Bu anlamda olgu bilimin tümüyle yabancı olmadığımız, bunun yanı sıra tam olarak anlamını kavrayamadığımız olguları araştırmak için uygun bir araştırma zemini oluşturduğunu ifade etmektedir. Bunun yanında olgu bilim deseninde kişisel tecrübelere de odaklanılmaktadır. Bu desende araştırmacı, katılımcının bireysel tecrübeleri ile ilgilenilmekte, algıları ve olaylara yüklediği anlamları incelemektedir. Tanılayıcı bir araştırma olan olgu bilimde genelleme yapmak yerine olguları tanımlamak önemsenir (Akturan ve Esen, 2008). Bu bağlamda araştırmada sınıf öğretmeni adaylarının "yapılandırmacı yaklaşım” kavramına ilişkin algı ve görüşleri tanılanmaya ve belirlenmeye çalış1lmıştır.

\section{Çalışma Grubu}

Bu araştırmanın çalışma grubunu 2019- 2020 eğitim öğretim yılında Dicle ve Marmara Üniversitesi Sınıf Eğitimi Ana Bilim Dalı'nın 4. sınıfında öğrenim gören 117 sınıf öğretmeni adayı oluşturmaktadır. Amaçlı örneklem tekniklerinden ölçüt örneklem kullanılarak araştırmanın çalışma grubu belirlenmiştir. Ölçüt örneklem tekniğinde çalışma grubu önceden belirlenmiş bir takım ölçütlere göre (Baltacı, 2018) belirlenmektedir. Araştırmada çalışma grubunun belirlenmesinde belirlenen ölçütler öğretmen adaylarının 4. sınıfta öğrenim görmesi, eğitim bilimleri, alan eğitimi (İlk Okuma Yazma Öğretimi, Hayat Bilgisi Öğretimi; Birleştirilmiş Sınıflarda Öğretim vd.), Okul Deneyimi ve Öğretmenlik Uygulaması derslerini almalarıdır. Araştırmada bu ölçütlerin oluşturulmasının nedeni, öğretmen adaylarının yapılandırmacı yaklaşım hakkında hem kuramsal anlamda bilgi sahibi olmaları hem de bu bilgilerin öğretim sürecinde uygulanmasını belirli bir düzeyde deneyimlemeleridir.

\section{Veri Toplama Aracı ve Süreci}

Araştırmaya katılan sınıf öğretmeni adaylarına "yapılandırmacı yaklaşım gibidir; çünkü ......." şeklinde ifadenin yazılı olduğu bir form verilmiştir. Onlardan yapılandırmacı yaklaşım kavramı ile ilgili sahip oldukları düşüncelere yoğunlaşarak tek bir metafor üretmeleri istenmiştir. Metaforların araç olarak kullanıldığg çalışmalarda (Aydın, 2010; Saban 2004, 2008, 2009) "gibi" kelimesi, genellikle "metaforun konusu" ile "metaforun kaynağı" arasındaki bağ daha açık bir şekilde çağrıştırmak için kullanılmaktadır. Bunun yanında cümlede "çünkü" kelimesine yer verilerek, araştırmaya katılan öğretmen adaylarından kendi metaforları için bir "gerekçe” sunmaları istenmektedir. Öğretmen adaylarına söz konusu formu doldurmaları için 
25 dakikalık bir süre verilmiştir. Öğretmen adayları tarafından doldurulan bu formlar toplanarak araştırma için temel veri kaynağı elde edilmiştir.

\section{Verilerin Analizi}

Çalışmada elde edilen veriler “metafor analizi” ve "içerik analizi” tekniği ile çözümlenmiştir. Yıldırım ve Şimşek (2011) içerik analizi tekniğinde verilerin belirli kavramlar ve temalar çerçevesinde bir araya getirilerek, okuyucular için organize edilip yorumlandığını ifade etmektedir. Bu araştırmada sınıf öğretmeni adaylarının "yapılandırmacı yaklaşım” kavramına ilişkin geliştirdikleri metaforlar aşağıda yer verilen aşamalara göre analiz edilerek yorumlanmıştır:

Adlandırma Aşaması: $\mathrm{Bu}$ aşamada çalışmaya katılan sınıf öğretmeni adayları tarafından üretilen metaforlar bilgisayara aktarılmıştır. Ardından alfabetik sıraya göre bu metaforlar sıralanarak geçici bir liste yapılmıştır.

Tasnif Etme (Eleme ve Arıtma) Aşaması: Bu aşamada metafor analizi ve içerik analizi teknikleri kullanılmış (Saban, Koçbekir ve Saban, 2006), her bir metafor parçalarına ayrılmış, diğer metaforlar ile olan benzerlik ve ortak özellik bakımından değerlendirilmeye çalışılmıştır. Öğretmen adayları tarafından geliştirilen metaforlar tek tek okunup gözden geçirilerek, her bir metafor; (1) metaforun konusu, (2) metaforun kaynağ 1 ve (3) metaforun konusu ile metaforun kaynağı arasındaki ilişki bakımından analiz edilmiştir.

Bu aşamada 117 formun 21'i “zayıf yapılı metafor" olarak değerlendirilmiştir. Bunların zayıf yapılı metafor olarak değerlendirilmesinin nedenleri herhangi bir metafor içermemesi, metafor kaynağı hakkında bilgi vermemesi, metaforun konusu ile metafor kaynağı arasında mantıklı bir gerekçe sunmaması, birden fazla metafor veya gerekçe yazılmasıdır. Bu bakımdan bunlar veri setinin dişında tutulmuştur.

Kategori Geliştirme Aşaması: Burada sınıf öğretmeni adayları tarafından geliştirilen metaforlar, "yapılandırmacı yaklaşım” kavramına ilişkin sahip oldukları ortak özelliklere göre incelenerek 10 kavramsal kategori oluşsturulmuştur.

Geçerlik ve Güvenirliği Sağlama Aşaması: Çalışmanın geçerliliğini sağlamak için verilerin analizi süreci ayrıntılı olarak açıklanmaya çalışılmıştır. Bulgular bölümünde elde edilen kategorileri en iyi temsil ettiği düşünülen açıklamalardan örnekler verilmiştir. Bunun yanı sıra elde edilen bulgular ile ilgili araştırmaların sonuçları arasında tutarlılığa bakılmıştır. Ayrıca araştırmanın güvenirliğini artırma adına uzman görüşü alınmıştır. Bu doğrultuda, nitel araştırma konusunda çalışmaları olan sınıf eğitiminde doktora eğitimini tamamlamış iki uzmana iki adet liste verilmiştir. Bu listelerin ilkinde 80 adet metafor alfabetik olarak 
sıralanmıştır. İkinci listede ise 10 farklı kavramsal kategorinin adları ve özelliklerine yer verilmiştir. Uzmanlardan bu iki listeyi kullanarak birinci listedeki metaforları, ikinci listedeki kavramsal kategorilerle (hiçbir metafor dişarıda bırakılmayacak şekilde) eşleştirmeleri istenmiştir. Daha sonra uzmanların yaptığı eşleştirmeler, araştırmacının kendi kategorileri ile karşılaştırılmıştır. Karşılaştırmalar sonucunda kodlayıcılar arasında güvenirlik Miles ve Huberman (1994)'ın formülü (Güvenirlik = görüş birliği / görüş birliği + görüş ayrılı̆̆g) kullanılarak hesaplanmıştır. Bu hesaplamaya göre \%86 oranında bir uzlaşma sağlanmıştır. $\mathrm{Bu}$ bakımdan araştırmada geçerlik ve güvenirlik çalışmalarının yapıldığını ifade etmek mümkündür.

Verileri Bilgisayar Ortamına Aktarma Aşaması: Toplam 80 metaforun belirlenmesinin ve bu metaforların oluşturduğu 10 adet kavramsal kategorinin geliştirilmesinin ardından bütün veriler bilgisayar ortamına aktarılmıştır. Daha sonra katılımcı sayısı (f) hesaplanmıştır. Verilerin sunumunda öğretmen adaylarına verilen kod isim kullanılmıştır. Örneğin ÖA1 birinci öğretmen adayını ifade etmektedir.

\section{Etik Kurul Kararı}

Dicle Üniversitesi Sosyal ve Beşeri Bilimler Etik Kurulu Başkanlığı'nın, 28/04/2020 tarih ve 43785 sayılı oluru gereği çalışma açısından Sosyal ve Beşeri Etik Kuralları ve İlkeleri çerçevesinde herhangi bir sakınca olmadığına karar verilmiştir.

\section{Bulgular}

Bu aşamada araştırma soruları başlıkları altında verilerin analizi ile elde edilen bulgular sunulmuştur.

\section{Sınıf Öğretmeni Adaylarının Yapılandırmacı Yaklaşım İle İlgili Ürettikleri}

\section{Metaforlar}

Yapılandırmacı yaklaşım ile ilgili sınıf öğretmeni adayları tarafından üretilen metaforların listesi Tablo 1'de sunulmuştur.

Tablo 1. Sınıf Öğretmeni Adaylarının Yapılandırmacı Yaklaşıma İlişkin Ürettikleri Metaforlar ve Bunların Frekansları

\begin{tabular}{clll}
\hline Üretilen Metaforlar & f & Üretilen Metaforlar & f \\
\hline 1. Ağaç & 1 & 41. İcat ve keşif yapma & 1 \\
2. Akan bir nehirde kabını doldurma & 1 & 42 . İşaat & 2 \\
3. Akıl & 1 & 43. Keşfederek öğrenme & 1 \\
4. Annelik & 1 & 44. Kuş & 1 \\
5. Anlamlı öğrenme & 1 & 45. Kuzey yıldızı & 2 \\
6. Bal arısı & 1 & 46. Mühendislik & 1 \\
7. Balık tutma & 1 & 47. Odun ateşi & 2
\end{tabular}


8. Balık tutmayı öğrenme

9. Balık nasıl tutulur kısmını öğretme

10. Bilgeliğe giden yol

11. Bilimsel bir keşif oyunu

12. Bina inşa etme

13. Bilginin yeniden yapılandırılması

14. Bilgiyi beynin süzgecinden geçirmek

15. Bilgiyi kendi ellerinle yeniden inşa etmek

16. Bilgiyi öğrenme

17. Bisiklet sürmek

18. Bir adada mahsur kalan çocuk

19. Bir ağaç

20. Bir ağaçtan bir çok çeşit meyve almak 1

21. Bir ağaç büyürken gösterdiği gelişim evresi 1

22. Bir binayı inşa etmek

23. Bir binanın inşası

24. Bir evin temeli

25. Bir evin yapıllışı

26. Bir futbol maçı

27. Çocuk

28. Çocuğa balık tutmayı öğretmek

29. Dershaneye gitmeden Kpss'ye hazırlanmak 1

30. Ev yemeği

31. Fidan yetiştirme

32. Gelecek zaman

33. Gökkuşağı

34. Güneş

35. Halo etkisi

36. Her şeyin sorumluluğunu alma

37. Hayat

38. Hayatı yaşamayı öğrenmek

39. Hayatın kendisi
1 48. Oyun hamuru 1

1 49. Oyunla öğretim 1

1 50. Öğrenciye malzeme verip yemek1 yapmasin 1 isteme

51. Öğrenmeyi öğretmek 1

52. Öğrencinin öğretmen olması 1

53. Örgü örmek 1

54. Özgürce bozkırda öğrenme 1

55. Özgürlük 2

56. Puzzle 1

57. Rengarenk çiçeklerle dolu bahçe 1

58. Resim 1

59. Resim yapmak 1

60. Ressamlik 1

61. Sahada futbolcu olmak 1

62. Saklı hazineyi bulmak 1

63. Sandalla okyanusun ortasında kalma 1

64.Sandik 1

65. Sepet 1

66. Şiir 1

67. Telefon oyunu oynama 1

68. Vadi arasından akan berrak su 1

69. Yaşantı deneyim 1

70. Yaşam 2

71. Yaşam ile iç içe olma 1

72. Yaşamın kendisi 5

73. Yaparak yaşayarak öğrenmeyi1 sağlayan bir bilet

74. Yapboz 2

75. Yapboz yapmak 1

76. Yeni bir şey oluşturma 1

77. Yemek 1

78. Yemek yapmayı öğrenmek 1

79. Yeşermeye başlayan bir ağaç 1
40. Heykeltraş
1
80. Zengin zeka dünyalarına açılan kapı 1

Toplam

96

Tablo 1 incelendiğinde yapılandırmacı yaklaşım kavramı ile ilgili sınıf öğretmeni adaylarının toplam 80 adet geçerli metafor ürettikleri, kimi metaforların ise birden fazla üretildiği görülebilmektedir (toplam 96 görüş). Sınıf öğretmeni adayları tarafından "hayat" ve "yaşamın kendisi”" metaforları beşer kez ; "bir binanın inşası”, “çocuk”, "inşaat”, "kuzey yıldızı"," odun ateşi”, “özgürlük”, “yaşam” ve” yapboz” metaforları da ikişer defa ifade edilmiştir. Geriye kalan metaforlar ise birer kez sınıf öğretmeni adayları tarafından üretilmiştir. $\mathrm{Bu}$ verilerden hareketle yapılandırmacı yaklaşım ile ilgili sınıf öğretmeni adayları tarafından oldukça farklı ve fazla metafor üretildiği söylenebilir. Sınıf öğretmeni adayları tarafından üretilen metaforların özellikleri bakımından sınıflandırıldığı kategoriler ise aşağıda sunulmuştur. 


\section{Sınıf Öğretmeni Adaylarının Yapılandırmacı Yaklaşım Kavramına İlişkin Sahip}

\section{Oldukları Metaforların Oluşturduğu Kategoriler}

Sınıf öğretmeni adaylarının yapılandırmacı yaklaşım kavramına ilişkin ürettikleri metaforların özelliklerine göre sınıflandırıldığı kategoriler Tablo 2'de sunulmuştur.

Tablo 2. Sınıf Öğretmeni Adaylarının Yapılandırmacı Yaklaşım Kavramına İlişkin Sahip Oldukları Metaforların Oluşturduğu Kategoriler

\begin{tabular}{|c|c|c|}
\hline Kategoriler & Metaforlar & $\mathbf{f}$ \\
\hline Öğrenciyi Aktif Kılma & $\begin{array}{l}\text { Akan bir nehirde kabını doldurma, bal arısı, balık nasıl tutulur } \\
\text { kısmını öğretme, bir futbol maçı, bilgiyi öğrenme, bir binanın } \\
\text { inşası (2), bir ağaç, bir adada mahsur kalan çocuk, çocuğa } \\
\text { balık tutmayı öğretmek, bilimsel keşif oyunu, her şeyin } \\
\text { sorumluluğunu almak, icat keşif yapmak, keşfederek } \\
\text { öğrenme, Kuş, oyunla öğretim, öğrencinin öğretmen olması, } \\
\text { öğrenciye malzeme verip yemek yapmasını isteme, } \\
\text { öğrenmeyi öğretmek, özgürlük, özgürce bozkırda öğrenmek, } \\
\text { sahada futbolcu olmak, saklı hazineyi bulma, sandalla } \\
\text { okyanusun ortasında kalma, vadi arasından akan berrak su, } \\
\text { yaparak yaşayarak öğrenmeyi sağlayan bir bilet, yaşamın } \\
\text { kendisi, yemek yapmayı öğrenmek }\end{array}$ & 28 \\
\hline Anlamlı Bilgi Oluşturma & $\begin{array}{l}\text { Akıl, Anlamlı öğrenme, bilgi birikimi, bilginin yeniden } \\
\text { yapılandırılması, bilgiyi beynin süzgecinden geçirme, bilgiyi } \\
\text { kendi ellerinle yeniden inşa etme, bina inşa etme, bir binayı } \\
\text { inşa etme, bir evin temeli, bir evin yapılışı, çocuk, dershaneye } \\
\text { gitmeden Kpss'ye hazırlanma, hayat (3), inşaat (2), örgü } \\
\text { örmek, sandık, yaşamın kendisi, yapboz, puzzle, }\end{array}$ & 22 \\
\hline Yaşam İle İlişkili Olma & $\begin{array}{l}\text { Hayat (2), hayatı yaşamayı öğrenmek, hayatın kendisi, yaşam } \\
(2) \text {, yaşam ile iç içe olma, yaşamın kendisi (3), yaşantı ve } \\
\text { deneyim. }\end{array}$ & 11 \\
\hline Gelişimin İfadesi & $\begin{array}{l}\text { Ağaç, gökkuşağı, bilgeliğe giden yol, bir ağaç büyürken } \\
\text { gösterdiği gelişim evresi, fidan yetiştirmek, odun ateşi (2), } \\
\text { Telefon oyunu oynama, yeşermeye başlayan bir ağaç, }\end{array}$ & 9 \\
\hline Yaratıcılık ve Özgünlük & $\begin{array}{l}\text { Annelik, heykeltıraş, mühendislik, oyun hamuru, resim, } \\
\text { ressamlık, yeni bir şey oluşturma, resim yapma }\end{array}$ & 8 \\
\hline Bireysel Farklılıklara Odaklanma & $\begin{array}{c}\text { Güneş, özgürlük, rengarenk farklı çiçeklerle dolu bir bahçe, } \\
\text { şiir, yapboz, zengin zeka dünyalarına açılan bir kapı, Bir } \\
\text { ağaçtan bir çok çeşit meyve almak }\end{array}$ & 7 \\
\hline $\begin{array}{l}\text { Uygulanmasının Çaba ve Emek } \\
\text { Gerektirmesi }\end{array}$ & Çocuk, ev yemeği, yapboz yapma, bisiklet sürmek & 4 \\
\hline Kalıcı Bilgi Oluşturma & Balık tutma, balık tutmayı öğrenme, sepet, & 3 \\
\hline Değişim ve Sürekliliği Gerektirme & Gelecek zaman, halo etkisi, yemek & 3 \\
\hline $\begin{array}{r}\text { Rehber ve Yol Gösterici Olma } \\
\text { Toplam }\end{array}$ & Kuzey y1ldızı (2) & $\begin{array}{c}2 \\
97\end{array}$ \\
\hline
\end{tabular}


Tablo 2 incelendiğinde yapılandırmacı yaklaşım ile ilgili sınıf öğretmeni adaylarının en fazla metafor ürettikleri kategorinin "Öğrenciyi aktif k1lma” (f:28) olduğu görülebilmektedir. Bu kategoriyi "Anlamlı bilgi oluşturma süreci” (f:22), "Yaşam ile ilişkili olma” (f:11), “Gelişimin ifadesi” (f:9), "Yaratıcılık ve özgünlük” (f:8), "Bireysel farklılıklara odaklanma" (f:7) kategorileri izlemektedir. Sınıf öğretmeni adayları tarafından üretilen metaforların görece daha az sınıflandırıldığı kategoriler ise, "Uygulanmasının çaba ve emek gerektirmesi” (f:4), "Kalıcı bilgi oluşturma” (f:3), "Değişim ve sürekliliği gerektirme” (f:3) ve "Rehber ve yol gösterici olma” (f:2) olmuştur. Görüldüğü üzere yapılandırmacı yaklaşım kavramı ile ilgili sınıf öğretmeni adayları tarafından üretilen metaforların sınıflandırıldığı kategorilerin sayısı oldukça fazladır. Aşağıda özellikleri yönüyle kategorilere göre sınıflandırılan metafor örnekleri sunulmuştur.

\section{Öğrenciyi Aktif Kılma}

$\mathrm{Bu}$ kategoride öğretmen adayları tarafından 28 adet metafor üretilmiştir. Bu kategoride yer alan metaforlar ile açıklama cümlelerinde, sınıf öğretmeni adaylarının yapılandırmacı yaklaşımın öğrenme sürecinde öğrencileri aktif kılmasına daha fazla odaklandıkları ve bu duruma ilişkin daha fazla açıklama yaptıkları tespit edilmiştir. Öğretmen adayları tarafından söz konusu kategoride üretilen metaforların bazıları şöyledir:

ÖA70: "Yapılandırmacı yaklaşım öğrencinin öğretmen olması gibidir. Çünkü yapılandırmacı yaklaşımda öğrenci aktif. Kendi öğrenmesinde sorumlu. Öğrenmeyi araştırarak keşfederek ögreniyor."

ÖA34: "Yapılandırmacı yaklaşım çocuğa balık vermek değil balık tutmayı ögrretmek gibidir. Çünkü yapılandırmacı yaklaşım çocuğun öğrenme sürecine aktif katıldı̆̆g, aktif rol aldı̆̆ı bir yaklaşımdır. Öğretmen öğrencileri destekler ve bazen ipuçları verir. Fakat çocuğun bilgiye kendisinin ulaşması beklenir. Çocuğa balık vermek kolaydır. Asıl önemli olan balık tutmayı ögretmektir."

ÖA44: "Yapılandırmacı yaklaşım özgürce bozkırda öğrenmek gibidir. Çünkü öğrenci merkezdedir. Biz ona ana yola çıkmasını sağlayacak o ilk adımları veririz. Geri kalanı öğrenci kendi çabası ile öğrenir.”

ÖA64: "Yapılandırmacı yaklaşım her şeyin sorumluluğunu almak gibidir. Çünkü ögrenciler bu yaklaşımla her şeyi kendi kendine yaparak yaşayarak öğrenir ve ögrrenmelerinin sorumluluğunu alır.”

Ö40: "Yapılandırmacı yaklaşım saklı olan hazineyi bulmak gibidir. Çünkü ögrrenciye bilgiler hemen gelmez, ögrencilerin fikir yürüterek bulması istenir. Öğrenci kendisine verilen 
YYÜ Eğitim Fakültesi Dergisi (YYU Journal of Education Faculty), 2021; 18(1)766-795, http://efdergi.yyu.edu.tr,

ipuçlarından yola çıkarak bilgiye ulaşır. Tıpkı haritadaki ipuçlarından yola çıkarak hazineyi bulmak gibi."

\section{Anlamlı Bilgi Oluşturma}

$\mathrm{Bu}$ kategoride sınıf öğretmeni adayları tarafından 22 metafor üretilmiştir. Üretilen metaforların açıklama cümlelerinde sınıf öğretmeni adaylarının yapılandırmacı yaklaşımın bireysel ve anlamlı bilgi oluşturma sürecine ilişkin açıklamalar yaptıkları görülmüştür. $\mathrm{Bu}$ kategoride öğretmen adayları tarafından üretilen metaforların bazıları şunlardır:

ÖA121: "Yapılandırmacı yaklaşım dershaneye gitmeden KPSS'ye hazırlanmak gibidir. Çünkü doğrudan bilgi almayan öğrenci (bir öğreticiden doğrudan aktarllan bilgi yerine), kendinde var olan bilgiler ile yeni öğrendiği bilgileri anlamlı hale getirmeye çalışarak konuları bitirmeye çalışır.”

ÖA41: "Yapılandırmacı yaklaşım bilgiyi kendi ellerinle inşa etmek gibidir. Çünkü bu zamana kadar bilgiler olduğu gibi önümüze kondu ve bizler de sorgulamadan mantı̆̆ını kavramadan bilgiyi ezberledik. Yapılandırmacı yaklaşım ise bunun tam tersini bizlere gösteriyor. Önemli olan bilgiyi zihnimize kazımak değil o bilgiyi anlamlandırarak içselleştirmek yani bilgiyi inşa etmek.”

ÖA30: "Yapılandırmacı yaklaşım bilgiyi beynin süzgecinden geçirmek gibidir. Çünkü yapılandırmacı yaklaşımda bilgiyi oluşturan kişinin kendisidir. Dışarıdan alınan bilgiyi kendine göre oluşturmaktadır. Oluşturulan bilgi kişi tarafından yapılandırılmış olduğu için unutulması geç olur ve daha iyi ögrenilir.”

ÖA43: "Yapılandırmacı yaklaşım sandık gibidir. Çünkü bir sandı̆̆a kendine ait eşyaları anıları koyarsın. Sandığın içini kendin doldurursun. Öğrenciler de böyle kendi öğrendiklerini

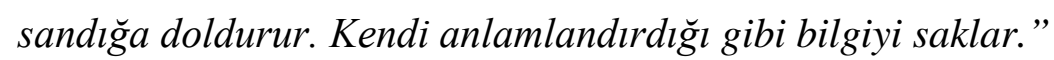

\section{Yaşamla İle İlişkili OIma}

$\mathrm{Bu}$ kategoride sınıf öğretmeni adayları tarafından 11 adet geçerli metafor üretilmiştir. $\mathrm{Bu}$ kategoride sınıflandırılan metaforların açıklama cümlelerinde, öğretmen adaylarının yapılandırmacı yaklaşımın yaşam ile ilişkisine ve yaşamsal bilgileri öğrenenlere kazandırma amacına ilişkin açıklamalar yaptıkları saptanmıştır. Bu kategoride üretilen metaforların bazıları aşağıda sunulmuştur:

Ö5: "Yapılandırmacı yaklaşım hayat gibidir. Çünkü birey hayatı yaşayarak ister istemez ihtiyaçlar doğrultusunda yeni şeyler ögrrenmek zorunda kalır. Yapılandırmacılık hayatı yaşamaktır. Hayatı yaşamak için öğrenme kaçınılmazdır. “ 
Ö29: "Yapılandırmacı yaklaşım yaşam gibidir. Çünkü yapılandırmacı yaklaşımda eğitim okulu hayatın kendisi olarak öğrenciye sunar. Okul hayatında formalite bilgi aktarmak yerine işlevsel ve çözüm odaklı bilgileri öğrenciye kazandırır. Bilgiyi deneyimleyerek kavramasına olanak sağlar. “

Ö34: "Yapılandırmacı yaklaşım hayatı yaşamayı öğrenmek gibidir. Çünkü çocuk her zaman her dersi yaparak yaşayarak öğrenir. Öğrendiklerini hayatta kullanır. Hayatın okul dışında kalan zamanlarında da ögrenme süreci devam eder."

\section{Gelişimin İfadesi}

$\mathrm{Bu}$ kategoride sınıf öğretmeni adayları tarafından dokuz adet geçerli metafor üretilmiştir. $\mathrm{Bu}$ kategoride sınıflandırılan metaforların açıklama cümlelerinde öğretmen adayları yapılandırmacı yaklaşımın öğrenenleri geliştirmesine ilişkin açıklamalar yapmıştır. $\mathrm{Bu}$ kategoride sınıflandırılan metaforların bazıları aşağıda sunulmuştur:

Ö18: "Yapılandırmacı yaklaşım gökkuşağı gibidir. Çünkü öğrenciyi her alanda geliştirmeyi, değiştirmeyi, şekillendirmeyi amaçlar. Çăgdaş ve gelişimsel eğitime dayandırarak gökkuşă̆ının nasıl çeşit çeşit rengi varsa ögrencide de çok çeşitli özellikler oluşturmak istenir. Her ögrenci birer yağmur damlasıdır ve eğitimden sonra olan değişsimler de gökkuşă̆ını simgeler.”

Ö115: "Yapılandırmacı yaklaşım odun ateşi gibidir. Çünkü odun eklendikçe harareti artar. Bilgi aldıkça kişi gelişir ve yapılandırmacılık kişiyi farklı bir boyuta yerleştirir. ”

Ö91: "Yapılandırmacı yaklaşım bilgeliğe giden yol gibidir. Çünkü yapılandırmacı yaklaşım kişinin kendisini gelişstirmesi, bilgiyi araştırması, bilgi dăgarcı̆̆ını geliştiren bir yol olduğu için yapılandırmacı yaklaşım bilgeliğe giden bir yol gibidir.”

\section{Yaratıcılık ve Özgünlük}

Bu kategoride sınıf öğretmeni adayları tarafından sekiz adet geçerli metafor üretilmiştir. Bu kategoride sınıflandırılan metaforların açıklama cümlelerinde, sınıf öğretmeni adaylarının yapılandırmacılığın hem öğrencilerin hem de öğretmenlerin yaratıcılığını geliştirdiğine dair ifadelere yer verdikleri saptanmıştır. Bu metaforların bazıları aşağıda sunulmuştur:

Ö3: "Yapılandırmacı yaklaşım ressamlık gibidir. Çünkü öğrenci yeni bir üretir. Kendisi düşünür, şekillendirir ve özgün şeyler geliştirir. Daima daha ressam gibi daha iyiyi ya da daha farklı şeyler çizmeye resmetmeye çalışır."

Ö28. "Yapılandırmacılık yeni bir şey oluşturmak gibidir. Çünkü yapılandırmacılık sayesinde kişi zihninde yeni bir şey tasarlayarak eylemsel ya da bilişsel olarak yeni bir şey 
oluşturur. Aslında lego ile bir ev, bir robot yapmak gibidir. Ortada bir nesne, olgu ve düşünce vardır. Kişi bunu alıp yeni ve orijinal bir şey yaratır."

Ö24: "Yapılandırmacılık anneliğe benzer. Çünkü anneler çocukları yetiştirirken birçok kez kendilerine özgü bir yetiştirme tarzı oluştururlar.”

\section{Bireysel Farklılıklara Odaklanma}

Bu kategoride sınıf öğretmeni adayları tarafından yedi adet geçerli metafor üretilmiştir. $\mathrm{Bu}$ kategoride sınıflandırılan metaforların açıklama cümlelerinde öğretmen adayları, yapılandırmacı yaklaşımın öğrenenleri merkeze almasına ve onların bireysel farklılıklarına odaklanmasına ilişkin açıklamalar yapmıştır. Bu kategoride sınıflandırılan metaforların bazıları aşağıda sunulmuştur:

Ö55: "Yapılandırmacı yaklaşım zengin zeka dünyalarına açılan kapı gibidir. Çünkü yapılandırmacı yaklaşım bireysel farklılıklara önem verir. Farklı zekalara hitap eden ögretme yaklaşımıdır.

Ö37: "Yapılandırmacı yaklaşım rengarenk farklı bahçelerle dolu bahçe gibidir. Çünkü yapılandırmacı yaklaşım bireysel farklılıkları göz önünde tutarak öğrenciyi aktif kılan bir eğitim yaklaşımı olduğu için her ögrencinin farklılıklarını, farklı bakış açılarını ve düşüncelerini eğitim ortamına taşırız. Her öğrenci diğerinden apayrı bir dünyadır. Sınıf da bu farklılıkları bir arada tutan ve her birine saygl duyan, her birini özümseyen bir ortam olmalıdır."

\section{Uygulanmasının Çaba ve Emek Gerektirmesi}

Bu kategoride sınıf öğretmeni adayları tarafından dört adet geçerli metafor üretilmiştir. $\mathrm{Bu}$ kategoride sınıflandırılan metaforların açıklama cümlelerinde öğretmen adaylarının yapılandırmacı yaklaşımın uygulanırken çaba ve emek gerektirmesine yönelik ifadelere yer verdikleri gözlenmiştir. Bu kategoride sınıflandırılan metaforların bazıları aşağıda sunulmuştur:

Ö50: "Yapılandırmacı yaklaşım çocuk gibidir. Çünkü ĕglenceli olduğu kadar sürekli ilgilenilmek ister."

Ö92: Yapılandırmacı yaklaşım yapboz yapma gibidir. Çünkü bir şeylere ulaşmak için çaba söz konusudur."

\section{Kalıcı Bilgi Oluşturma}

Bu kategoride sınıf öğretmeni adayları tarafından üç adet geçerli metafor üretilmiştir. Bu kategoride sınıflandırılan metaforların açıklama cümlelerinde öğretmen adayları daha çok yapılandırmacı yaklaşımın kalıcı bilgi oluşturmasına ilişkin açıklamalar yapmıştır. $\mathrm{Bu}$ kategoride sınıflandırılan metaforların bazıları aşağıda sunulmuştur: 
Ö58: "Yapılandırmacı yaklaşım sepet gibidir. Çünkü bilgiler öğrenildikçe her bilgiyi sepete atarlz. Ne kadar yaparak yaşayarak öğrenirsek o bilgiler sepetimizde çürümez, ömrü uzun ve kalıcı olur. Davranışçı eğitimde kişiler kısa süreliğini bilgili olur.”

Ö80: "Yapılandırmacı yaklaşım balık tutmayı öğrenmek gibidir. Çünkü yapılandırmacı yaklaşımla birey bilgiye kendi çabalarıyla erişebilir. Kalıcı bir öğrenme oluşur. Bilgiler hayat boyu ögrenilir."

\section{Değişim ve Sürekliliği Gerektirme}

Bu kategoride sınıf öğretmeni adayları tarafından üç adet geçerli metafor üretilmiştir. $\mathrm{Bu}$ kategoride sınıflandırılan metaforların açıklama cümlelerinde öğretmen adayları, yapılandırmacı yaklaşımın değişimi ve sürekliliği gerektirmesine ilişkin açıklamalar yapmıştır. Bu kategoride sınıflandırılan metaforlar aşağıda sunulmuştur:

Ö16: "Yapılandırmacı yaklaşım yemek gibidir. Çünkü her gün geliştirilerek yeniden yapılması gerekir."

Ö124: "Yapılandırmacı yaklaşım halo etkisi gibidir. Çünkü bir kişi bu şekilde eğitim verdiğinde çevresindekileri de bu şekilde eğitmişs olacak. Bu ĕgitilenler bir başkasını böyle ĕgittiğinde halo etkisi gibi yayılacaktır."

\section{Rehber ve Yol Gösterici Olma}

Bu kategoride sınıf öğretmeni adayları tarafından iki adet geçerli metafor üretilmiştir. $\mathrm{Bu}$ kategoride sınıflandırılan metaforların açıklama cümlelerinde öğretmen adayları yapılandırmacı yaklaşımın rehber ve yol gösterici olmasına dair açıklamalar yapmıştır. $\mathrm{Bu}$ kategoride sınıflandırılan metaforlar aşağıda sunulmuştur:

Ö83: "Yapılandırmacı yaklaşım kuzey yıldızı gibidir. Çünkü öğrencinin karanlıkta bile olsa yol bulduğu bir yaklaşımdır.”

\section{Tartışma ve Sonuç}

Araştırmada sınıf öğretmeni adaylarının toplam 80 metafor ile 96 görüş geliştirdikleri saptanmıştır. $\mathrm{Bu}$ görüşler 10 kategoride sınıflanmıştır. Sınıf öğretmeni adaylarının yapılandırmacı yaklaşım kavramı ile ilgili bu kadar fazla metafor üretmesinin bir nedeni kavramın kapsamının genişliği olabilir. İlgili literatürde görüldüğü üzere yapılandırmacılık bilgi felsefesi, öğrenme anlayışı ve öğretim yaklaşımı olarak ele alınmaktadır (Duffy ve Cunningham, 1996; Haney ve McArtur, 1999; Savery ve Duffy, 1995). Öğretmen adaylarının kavram ile ilgili fazla metafor üretmesinin bir diğer nedeni ise kavramın karmaşıklığı da olabilir. Nitekim Doolittle (2014) yapılandırmacılığı karmaşıklık teorisi ile ilişkilendirerek açıklamaya çalışmaktadır. Bu bağlamda öğretmen adaylarının yapılandırmacı yaklaşım ile ilgili 
çok fazla metafor üretmelerinin ve bu metaforların çok çeşitli kategorilerde sınıflanmasının nedeni kavramın karmaşık yapısı ve kapsamının genişliği olabilir.

Sınıf öğretmeni adaylarının yapılandırmacı yaklaşım kavramına ilişkin ürettikleri metaforlar 10 kategoride sınıflandırılmıştır. Bunlardan “Öğrenciyi aktif kılma” kategorisi sınıf öğretmeni adayları tarafından üretilen metaforların en fazla sınıflandırıldığı kategori olmuştur. Bu kategori altında toplam 28 metafor yer almaktadır. Perkins (1999) yapılandırmacilikta öğrencilerin aktiflik, yaratıcılık ve sosyallik olmak üzere üç farklı rollerinin bulunduğunu ifade etmektedir. Buna göre öğrenciler öğrenme sürecine aktif katılmalı, öğrendikleri bilgileri arkadaşları ile sosyal ortamda anlamlandırmalı ve yeni problem durumlarında kullanarak benzersiz bilgileri üretebilmelidir. İşman, Baytekin, Balkan, Horzum ve Kıyıcı (2002) ise yapılandırmacı yaklaşımda öğrencilerin kendi öğrenmelerinden sorumlu olarak ve işbirliği ile çalışarak problem çözücü olmaları gerektiğini belirtmektedir. Bu bakımdan yapılandırmacı yaklaşımın öğrencilere öğrenme sürecine aktif olarak katılım rolünü verdiğini ifade etmek mümkündür. Günay ve Yücel Toy (2015) tarafından yapılan araştırmada, eğitim fakültelerinde görev yapan öğretim elemanlarının “yapılandırmacı eğitim” ile ilgili ürettikleri metaforlar en fazla “yaparak yaşayarak öğrenmeyi sağlayan eğitim” kategorisinde sınıflandırılmıştır. Öğretim elemanlarının bu kategoride sınıflanan görüşlerinde, yapılandırmacı eğitim sürecinde öğrencilerin aktif kılınmasına odaklandıklarını ifade edebilmek mümkünüdür. Sınıf öğretmeni adaylarının ürettiği metaforların en fazla öğrenciyi aktif kılma kategorisinde sınıflandırılmasının nedeni, üniversite eğitimi sürecinde yapılandırmacı yaklaşım ile ilgili aldıkları derslerde öğretim elemanlarının yapılandırmacı yaklaşımın öğrencileri aktif kıldığı yönündeki değerlendirmeleri olabilir.

Sınıf öğretmeni adayları tarafından geliştirilen metaforların en fazla sınıflandırıldığ ikinci kategori ise "Anlamlı bilgi oluşturma" kategorisidir. Bu kategori altında 22 metaforun yer aldığı görülmektedir. Bu bakımdan araştırmaya katılan sınıf öğretmeni adaylarının önemli bir bölümün yapılandırmacı yaklaşımı anlamlı bilgi oluşturma süreci olarak değerlendirdiğini söyleyebilmek mümkündür. Bu bulguya benzer şekilde Günay ve Yücel Toy (2015), eğitim fakültelerinde görev yapan öğretim elemanlarının “yapılandırmacı eğitim” kavramı ile ilgili ürettikleri metaforların önemli bölümünü "önbilgilerle yeni bilgileri inşa ettiren ettiğim” ile "Bilginin anlamlı bir şekilde akılda inşa edildiği bir eğitim” kategorileri altına sınıflamıştır. Thomas ve McRobbie (2001) yapılandırmacı öğrenme sürecini öğrencilerin "inşa” metaforu ile ifade ettiklerini, Dils (2004) mesleğe yeni başlayan öğretmenlerin yapılandırmacılığı bir takım 
uygulamalı etkinliklerle yeni şeylerin inşası olarak tanımladıklarını saptamıştır. Yapılandırmacı yaklaşımın anlamlı bilgiyi zihinde inşa sürecine ilişkin ortaya koyduğu fikirlerin öğrencilerin, öğretmen adaylarının, öğretmenlerin ve öğretim elemanlarının kavrama dair algılarını şekillenmesinde etkili olduğunu söyleyebilmek mümkündür.

"Yaşam ile ilişkili olma" olarak ifade edilen kategori, sınıf öğretmeni adaylarının yapılandırmacı yaklaşım ile ilgili en fazla metafor ürettiği üçüncü kategori olmuştur. $\mathrm{Bu}$ kategori altında 11 metafor sınıflandırılmıştır. Bu kategoride sınıflanan metaforların açıklama cümlelerinde sınıf öğretmeni adaylarının yapılandırmacı yaklaşımın yaşam ile ilişkisine vurgu yaptıkları görülmüştür. Yapılandırmacı yaklaşımın öğrenme ile ilgili ortaya koyduğu bakış açılarında, Dewey’in görüşlerinin temele alındığını (Albayrak, 2012) söyleyebilmek mümkündür. Dewey'in “okul yaşamın ta kendisi olmalıdır” görüşü yapılandırmacı öğrenme ile gerçek yaşam arasında ilişki olduğunu ortaya koymaktadır. Murphy (1997) de benzer şekilde yapılandırmacı öğrenme ortamlarında gerçek yaşam problemlerine odaklanılması ve ders konularının yaşamla ilişkisinin kurulmasının gerektiğini ifade etmektedir. Çünkü öğrenilecek konular ne kadar yaşamla ilişkili olursa öğrenciler için o kadar anlamlı olmaktadır. Sınıf öğretmeni adaylarının yapılandırmacı yaklaşım ile ilgili düşüncelerinin şekillenmesinde, ilgili literatürde yer alan bu açıklamaların etkisinin olabileceğini söyleyebilmek mümkündür.

“Gelişimin ifadesi” şeklinde isimlendirilen kategori, sınıf öğretmeni adaylarının yapılandırmacı yaklaşım ile ilgili en fazla metafor ürettiği dördüncü kategori olmuştur. $\mathrm{Bu}$ kategori altında dokuz metafor sınıflandırılmıştır. Yapılandırmacı öğrenme ortamları öğrencileri araştırmaya, tartışmaya, sorgulamaya ve problem çözmeye sevk etmektedir. Bu durum öğrencilerin üst düzey bilişsel (Aydın ve Yılmaz, 2010), sorgulayıcı düşünme (Akpınar, 2010; Balım, İnel ve Evrekli, 2010), problem çözme (Hançer ve Yalçın, 2009), eleştirel ve yaratıcı düşünme (Gömleksiz ve Kan, 2009) becerilerini geliştirmektedir. Bu bağlamda sınıf öğretmeni adaylarının yapılandırmacı yaklaşımın öğrencilerin gelişimine önemli katkılar sağladığını düşündükleri ve algılarının biçimlenmesinde bu düşüncelerin etkisinin olduğu söylenebilir.

"Yaratıcılık ve özgünlük” olarak ifade edilen kategori, sınıf öğretmeni adaylarının yapılandırmacı yaklaşım ile ilgili en fazla metafor ürettiği beşinci kategori olmuştur. $\mathrm{Bu}$ kategori altında sekiz metafor sınıflandırılmıştır. Öğretmen adaylarının bu kategoride ürettiği metaforların açıklama cümlelerinde yapılandırmacılığın hem öğrencilerin hem de 
öğretmenlerin yaratıcılığını geliştirdiğine dair ifadelere yer verdikleri saptanmıştır. Günay (2015) tarafından yapılan araştırmada eğitim fakültelerinde görev yapan öğretim elemanlarının yapılandırmacı öğretmen algılarının bir bölümünün özgün şeyler ortaya çıkaran öğretmen kategorisinde sınıflandırıldığı saptanmıştır. Tezci ve Gürol (2003), yapılandırmacılığın tüm bileşenlerinin öğrencilerin yaratıcılığı desteklediğini ifade etmektedir. Yapılandırmacı anlayışı benimseyen öğretmenlerin etkili bir öğretim süreci oluşturma adına özgün ve yaratıcı etkinlikler oluşturması, öğrencilerin de bir bakıma yaratıcılığını olumlu anlamda etkileyebilecektir denilebilir. Bu durumlar sınıf öğretmen adaylarının yapılandırmacı yaklaşım ile algılarının yaratıcılık ve özgünlük bağlamında şekillenmesinde etkili olmuş olabilir.

“Bireysel farklılıklara odaklanma” olarak ifade edilen kategori, sınıf öğretmeni adaylarının yapılandırmacı yaklaşım ile ilgili yedi metafor ürettiği kategoridir. Günay ve Yücel Toy (2015) çalışmasında öğretim elemanlarının yapılandırmacı eğitim algılarının bazılarını “bireysel farklılıklara önem veren demokratik eğitim” olarak sınıflamıştır. Yine Günay’ın (2015) araştırmasında eğitim fakültelerinde görev yapan öğretim elemanlarının yapılandırmacı öğretmen ile ilgili algılarının bazılarının "farklılıklara ve değerlere dikkat eden adil öğretmen” kategorisinde yer aldığı görülmektedir. Akar ve Yıldırım (2009) yapılandırmacı öğretim sürecini deneyimleyen öğretmen adaylarının sınıf yönetimine ilişkin metafor geliştirirken bireysel farklılıklara odaklandığını saptamıştır. Bu bulgulardan hareketle sınıf öğretmeni adaylarının yaklaşıma ilişkin algılarının bireysel farklılıklara odaklanma açısından biçimlenmesinde derslerine giren öğretim elemanlarının etkisinin olduğu söylenebileceği gibi yapılandırmacı yaklaşıma uygun öğrenme sürecini deneyimlemelerinin de etkisi olmuş olabilir.

"Uygulanmasının çaba ve emek gerektirmesi” olarak ifade edilen kategori, sınıf öğretmeni adaylarının yapılandırmacı yaklaşım ile ilgili dört metafor ürettiği kategoridir. Günay (2015) eğitim fakültesinde görev yapan öğretim elemanlarının yapılandırmacı öğretmeni öğretim sürecini tasarlayan, öğrencileri araştırmaya yönlendiren ve hazır bilgi vermeyen öğretmen olarak tanımladıklarını araştırmasında ortaya koymuştur. Temli Durmuş (2014) ise sınıf öğretmenlerinin yapılandırmacı yaklaşıma uygun öğretim etkinliklerini kalabalık sınıflar ve kısıtlı zamandan dolayı uygularken zorluklar yaşadıklarını tespit etmiştir. Bilindiği gibi yapılandırmacı yaklaşımda "öğrenmeyi öğretme” ilkesi yer almaktadır. Buna göre öğrencilerin bilgi yapılarını düzenlemeleri adına öğretmenlerin uygun bir öğretim ortamı oluşturması önemlidir (Albayrak, 2012). Böyle bir öğrenme ortamında, öğretmenin öğrencilerin çeşitli zihinsel çelişkiler yaşaması için uygun ipuçlarıyla üst düzey zihinsel becerilerin elde edilmesine imkân verebilmesi gerekmektedir (Ardıç, 2015). Ancak araştırma sonuçlarında da görüldüğü 
üzere yapılandırmacı öğrenme ortamlarını hazırlayabilme adına öğretmenler önemli anlamda çaba ve emek harcasalar bile uygulamada sorun yaşanabilmektedir (Çaycı ve Altunkeser, 2015 ). Bu durum öğretmenlerin fazladan çaba ve emek harcayarak öğrenme etkinliklerini oluşturup uygulamalarına neden olabilmektedir. Sınıf öğretmeni adaylarının yapılandırmacı yaklaşımın uygulanmasının emek ve çaba gerektirmesine ilişkin düşüncelere sahip olmalarının nedeni ele alınan bu durumlar olabilir.

“Kalıcı bilgi oluşturma süreci” olarak ifade edilen kategori, sınıf öğretmeni adaylarının yapılandırmacı yaklaşım ile ilgili üç metafor ürettiği kategoridir. Bu kategori ile yaşam ile ilişkili olma kategorisi arasında ilişki olabilir. Çünkü Kabapınar’a (2012) göre yapılandırmacı yaklaşımda öğrenilecek bilgilerin kalıcı olması için konular yaşamdan alınmaktadır. Yapılandırmacı yaklaşımın gerçek yaşamda karşılığı olan konu ve bilgilerin daha kalıcı ve anlamlı öğrenme sağlayabileceğine dair görüşler ortaya koyması, öğretmen adaylarının yaklaşıma ilişkin algılarının şekillenmesinde etkili olmuş olabilir. "Değişim ve sürekliliği gerektirmesi” olarak ifade edilen kategori, sınıf öğretmeni adaylarının yapılandırmacı yaklaşım ile ilgili üç metafor ürettiği kategoridir. Yapılandırmacı yaklaşım öğretmene önemli sorumluluklar yüklemektedir. Yapılandırmacı yaklaşıma göre öğretim sürecini tasarlamak, sınıfta olumlu bir öğrenme ortamı oluşturmak, öğrencilere bilgiye ulaşma yollarını göstermek için öğretmenin sürekli kendini geliştirmesi, bilgilerini yenileyerek olumlu anlamda değişim göstermesi gerekmektedir. Öğretmen adaylarının yapılandırmacı yaklaşımın uygulanmasının değişim ve sürekliliği gerektirmesi yönünde görüş ifade etmelerinin nedeni bir bakıma yapılandırmacılığın öğretmene yüklediği bu misyon olabilir.

"Rehber ve yol gösterici olma” olarak ifade edilen kategori, sınıf öğretmeni adaylarının yapılandırmacı yaklaşım ile ilgili iki metafor ürettiği kategoridir. Branş öğretmenleri ve öğretmen adayları ile yapılan metaforik araştırmalarda öğretmenin rehber olma özelliğinin ön plana çıktığı görülmektedir (Ben-Peretz, Mendelson ve Kron, 2003; Hamilton, 2016). Bu çalışmada ise rehber ve yol gösterici olma kategorisinde sınıf öğretmeni adaylarının görece az metafor ürettikleri saptanmıştır. Eminoğlu Küçüktepe ve Gürültülü (2014)’nün yaptıkları araştırmada, "rehber olarak öğretmen" kategorisinde branş öğretmenlerinin sınıf öğretmenlerine göre yapılandırmacı öğretmen kavramı ile ilgili daha fazla metafor ürettikleri görülmektedir. Bu bağlamda öğretmen adaylarının ve öğretmenlerin yapılandırmacı yaklaşım kavramına ilişkin algılarının şekillenmesinde branşın etkili bir faktör olduğu söylenebilir. Ayrıca sınıf öğretmeni adaylarının ürettikleri metaforların daha fazla sınıflandırıldığı kategorilerde (öğrenciyi aktif kılma, anlamlı bilgi oluşturma, bireysel farklılıklara odaklanma, 
gelişimin ifadesi) yer alan açıklamalarda öğrencilerin merkeze alındığı görülmektedir. "Rehber ve yol gösterici olma”, "değişim ve sürekliliği gerektirmesi” gibi görece az görüşlerin sınıflandırıldığı kategorilerde ise sınıf öğretmeni adaylarının öğretmen odaklı açıklamalara yer verdiği saptanmıştır. Bu bağlamda sınıf öğretmeni adaylarının "yapılandırmacı yaklaşım” kavramına ilişkin alg1 ve düşüncelerinin daha çok öğrenci merkezli olduğu söylenebilir.

Araştırmada elde edilen sonuçlara göre sınıf öğretmeni adaylarının yapılandırmacı yaklaşım ile ilgili algılarının daha çok yapılandırmacılığın bilgi felsefesi olması ve öğrenme sürecine bakış açısı ile ilgili ortaya koyduğu düşünceler ile ilgili olduğu görülebilmektedir. Ayrıca yapılandırmacılığın öğrenci gelişimine katkısı ve öğretmene yüklediği sorumluluklar da sınıf öğretmeni adaylarının yapılandırmacı yaklaşım algılarını şekillendirmektedir. Ancak yapılandırmacılığın öğrenme ortamına, değerlendirme sürecine ve öğrenme sürecinde materyal kullanımına olan etkilerine dair öğretmen adayları tarafından herhangi bir metafor üretilmemiştir. Bunun nedeni eğitim sürecinde yapılandırmacı yaklaşımın öğrenme ortamına, değerlendirme sürecine ve materyal kullanımına etkisi üzerinde görece az durulması, bu konularda öğretmen adaylarının daha az uygulama yapmaları ve deneyim eksikliği olabilir. Bundan dolayı sınıf eğitimi alanında görevli öğretim elemanları, yapılandırmacılığın öğrenme ortamı, materyal kullanımı ve değerlendirme sürecine etkisini ilgili derslerde vurgulayacak şekilde planlamalar ve uygulamalar gerçekleştirebilir. Ayrıca çalışmada elde edilen sonuçlara göre sınıf öğretmeni adaylarının yapılandırmacı yaklaşıma ilişkin algılarının oldukça olumlu olduğu saptanmıştır. Çaycı ve Altunkeser (2015) sınıf öğretmeni adaylarının yapılandırmacı yaklaşıma ilişkin tutum düzeylerinin oldukça yüksek olduğunu tespit etmiştir. Kasapoğlu ve Duban (2012) ise sınıf öğretmeni adaylarının yapılandırmacı yaklaşıma ilişkin tutumlarının yapılandırmacı öğretim süreci oluşturmaya ilişkin öz yeterlilik inancını olumlu anlamda etkilediğini ortaya koymuştur. Bu çalışmada sınıf öğretmeni adaylarının yapılandırmacı yaklaşım ile ilgili olumsuz sayılabilecek bir metafor ortaya koymamaları, öğretmenlik yaşantılarında yapılandırmacı yaklaşıma uygun öğretim süreci oluşturma potansiyeline sahip olduklarına dair ip uçları sunmaktadır.

\section{Sınırlılıklar ve Öneriler}

$\mathrm{Bu}$ araştırmanın çalışma grubunun sadece sınıf öğretmeni adaylarından oluşması bir bakıma araştırmanın bir sınırlılığı olarak ele alınabilir. Araştırmacılar farklı branşlarda öğrenim gören öğretmen adaylarının yapılandırmacı yaklaşıma ilişkin algılarını saptayabilir. Bunun yanında görevde olan sınıf ve branş öğretmenlerinin yapılandırmacı yaklaşım ile ilgili algıları araştırılabilir. Ayrıca sınıf öğretmenliği eğitimi alanında öğretmen yetiştiren öğretim 
elemanları, sınıf öğretmeni adaylarının yapılandırmacı yaklaşım algısının şekillenmesinde etkisi fazla olan faktörler ile etkisi daha az olan görüş ve fikirleri dikkate alarak, alan eğitimi veya eğitim bilimleri derslerinin öğrenme sürecini tasarlayabilir.

\section{Makalenin Bilimdeki Konumu}

Temel Eğitim Bölümü/ Sınıf Eğitimi

\section{Makalenin Bilimdeki Özgünlüğü}

Literatürde öğretmen ve öğretmen adaylarının yapılandırmacı yaklaşıma ilişkin tutum, yeterlilik ve görüşlerinin belirlendiği çalışmalara rastlansa da sınıf öğretmeni adayları özelinde yapılandırmacı yaklaşım kavramına ilişkin görüşlerin metaforlar aracılığı ile ortaya konulduğu bir çalışmaya rastlanmamıştır. Bundan ötürü sınıf öğretmeni adaylarının yapılandırmacı yaklaşım kavramına ilişkin görüşlerinin metaforlar aracılığı ile belirlenmesiyle, sınıf eğitimi alanındaki paydaşlara önemli bilgi ve bakış açıları kazandırılabileceği düşünülerek çalışma gerçekleştirilmiştir.

\section{Kaynaklar}

Açıkgöz, K. (2003). Aktif öğrenme. İzmir: Eğitim Dünyası Yayınları.

Airasian, P. W ve Walsh, M. E. (1997). Constructivist cautions. Phi Delta Kappan, 78(6), 444449.

Akar, H. ve Yıldırım, A. (2009). Change in teacher candidates' metaphorical images about classroom management in a social constructivist learning environment. Teaching in Higher Education, 14(4), 401-415.

Akpınar, B. (2010). Yapılandırmacı yaklaşımda öğretmenin, öğrencinin ve velinin rolü. Ĕgitime Baklş Ĕ̈itim-Öğretim ve Bilim Araştırma Dergisi, 6(16), 16-20.

Akturan, U. ve Esen, A. (2008). Fenomenoloji. (Ed. Baş ve U. Akturan ), Nitel araştırma yöntemleri (ss. 83-98) içinde. Ankara: Seçkin Yayıncılık.

Albayrak, Y. (2012). Yapılandırmacı paradigma bağlamında ögretmenin rolünün incelenmesi Yayımlanmamış Yüksek Lisans Tezi, Sosyal Bilimler Enstitüsü, Maltepe Üniversitesi, İstanbul.

Ardıç, Ü. (2015). Orta öğretim öğrencilerinin yapılandırmacı öğrenme ortamlarına yönelik görüşlerinin incelenmesi (Ümraniye ilçesi örneği). Yayınlanmamış Yüksek Lisans Tezi, Eğitim bilimleri Enstitüsü, Yeditepe Üniversitesi, İstanbul. 
Aydın, F. (2010). Ortaöğretim öğrencilerinin coğrafya kavramına ilişkin sahip oldukları metaforlar. Kuram ve Uygulamada Eğitim Bilimler Dergisi (KUYEB), 10(3), 1313-1322. Aydın, N. ve Yılmaz, A. (2010). Yapılandırıcı yaklaşımın öğrencilerin üst düzey bilişsel becerilerine etkisi. Hacettepe Üniversitesi Ĕ̈itim Fakültesi Dergisi, 39(39), 57-68.

Balım, A. G., İnel, D. ve Evrekli, E. (2008). Fen öğretiminde kavram karikatürü kullanımının öğrencilerin akademik başarılarına ve sorgulayıcı öğrenme becerileri algılarına etkisi. İlkögretim Online, 7(1), 188- 202

Baltacı, A. (2018). Nitel araştırmalarda örnekleme yöntemleri ve örnek hacmi sorunsalı üzerine kavramsal bir inceleme. Bitlis Eren Üniversitesi Sosyal Bilimler Enstitüsü Dergisi,7(1), 231-274.

Beevevino, M. M., Dengel, J. ve Adams, K., (1999). Costructivist theory in the primary: Internalizing concepts through inquiry learning. The Clearing House, 72(5), 275-278.

Ben-Peretz, M., Mendelson, N. ve Kron, F. W. (2003). How teachers in different educational contexts view their roles. Teaching and Teacher Education, 19(2), 277-290.

Brooks, J. G. ve Brooks, M. G. (1993). In search of understanding: The case for constructivist primarys. Alexandria: VA: Association for Supervision and Curriculum Development.

Brooks, J. G. ve Brooks, M. G. (1999). The courage to be constructivist primarys. Educational Leadership,57(3), 18 -24.

Cerit, Y. (2008). Öğrenci, öğretmen ve yöneticilerin müdür kavramı ile ilgili metaforlara ilişkin görüşleri. Eğitim ve Bilim, 33(147), 3-13.

Çaycı, B. ve Altunkeser, F. (2015). Öğretmen adaylarının yapılandırmacı anlayışa yönelik tutumları ile etkililiğine yönelik görüşleri. Bartın Üniversitesi Eğitim Fakültesi Dergisi, ÖZEL SAYI, 44-61.

Delil, A. ve Güleş, S. (2007). Yeni ilköğretim 6. Sınıf matematik programındaki geometri ve ölçme öğrenme alanlarının yapılandırmacı öğrenme yaklaşımı açısından değerlendirilmesi. Uludă̆ Üniversitesi Eğitim Fakültesi Dergisi, 20(1), 35-48.

Demirel, Ö. (2008). Yapılandırmacı eğitim. Ĕ̆itim ve Öğretimde Çă̆daş Yaklaşımlar Sempozyumu, İstanbul: Harp Akademileri Basımevi.

Demirhan, C. ve Demirel, Ö. (2002) Program geliştirmede proje tabanlı öğrenme yaklaşımı. Abant İzet Baysal Üniversitesi Eğitim Fakültesi Dergisi, 3(5), 48-61.

Dils, A. K. (2004). The use of metaphor and technology to enhance the instructional planning of constructivist lessons. Contemporary Issues in Technology and Teacher Education, 4(2), 214-224. 
YYÜ Eğitim Fakültesi Dergisi (YYU Journal of Education Faculty), 2021; 18(1)766-795, http://efdergi.yyu.edu.tr,

Doolittle, P. E. (2014). Complex constructivism: A theoretical model of complexity and cognition. International Journal of Teaching And Learning in Higher Education, 26(3), 485-498.

Duffy, T. M. ve Cunningham, D. J. (1996). Constructivism: Implications for the design and delivery of instruction. In D. H. Jonassen (Ed.), Handbook of research for educational communications and technology (p. 170-198). New York: Simon \& Schuster/Macmillan.

Duman, B. (2004). Öğrenme-öğretme kuramlarl ve süreç temelli öğretim. Ankara: Anı Yayınc1lık.

Eminoğlu Küçüktepe, S. E. ve Gürültü, E. (2014). Öğretmenlerin "yapılandırmacı öğretmen" kavramına ilişkin algılarına yönelik metafor çalışması örneği. Abant İzzet Baysal Üniversitesi Ĕ̆itim Fakültesi Dergisi, 14(2), 282- 305

Erdamar Koç, G. ve Demirel, M. (2008). Yapılandırmacı öğrenme yaklaşımının duyuşsal ve bilişsel öğrenme ürünlerine etkisi. Türk Eğitim Bilimleri Dergisi, 6(4), 629-661.

Evrekli, E., İnel, D., Balım, A. G. ve Kesercioğlu, T. (2009). Fen öğretmen adaylarının yapılandırmacı yaklaşıma yönelik tutumlarının incelenmesi. Uludă̆ Üniversitesi Ĕ̆itim Fakültesi Dergisi, 22(2), 673-687.

Fer, S. ve Cırık, İ. (2007). Yapılandırmacı öğrenme-kuramdan uygulamaya. İstanbul: Morpa Yayınları.

Fox, R. (2001). Constructivism examined. Oxford Review of Education, 27(1), 23-35.

Geçit, Y. (2015). Sosyal bilgiler öğretmen adaylarının yapılandırmacı yaklaşıma yönelik tutumlarının incelenmesi. Recep Tayyip Erdoğan Üniversitesi Sosyal Bilimler Dergisi, 1(2), 176-185.

Gömleksiz, M. N. ve Kan, A. Ü. (2009). Sosyal bilgiler dersi öğretim programının eleştirel düşünme, yaratıcı düşünme ve girişimcilik becerilerini kazandırmadaki etkililiğinin belirlenmesi (Diyarbakır ili örneği). Fırat Üniversitesi Doğu Araştırmaları Dergisi, 8(1), 39-49

Günay, R. (2015). Eğitim fakültesinde görevli öğretim elemanlarının yapılandırmacı öğretmen algiları. Elementary Education Online, 14(3), 845- 861.

Günay, R. ve Yücel Toy, B. (2015). Metaphorical analysis of teacher trainers’ conceptualization of constructivist education. International Online Journal of Educational Sciences, 7(4), 51-68.

Hamilton, E. R. (2016). Picture This: Multimodal representations of prospective teachers' metaphors about teachers and teaching. Teaching and Teacher Education, 55, 33-44. 
Hançer, A. H. ve Yalçın, N. (2009). Fen eğitiminde yapılandırmacı yaklaşıma dayalı bilgisayar destekli öğrenmenin problem çözme becerisine etkisi. Gazi University Journal of Gazi Educational Faculty, 29(1), 55- 72.

Haney, J. J. ve McArthur, J. (2002). Four case studies of prospective science teachers' beliefs concerning constructivist teaching practices. Science Education, 86(6), 783-802.

Honebein, P. (1996) "Seven goals for the design of constructivist learning enviroments" http://studentcenteredlearning.pbworks.com/f/DesignConstructivistHonebein.pdf adresinden 05/06/2020 tarihinde alınmıştır.

İnel, D., Evrekli, E. ve Türkmen, L. (Eylül 2010). Sınıf öğretmeni adaylarının yapılandırmacı yaklaşıma ilişkin görüşlerinin ve tutumlarının incelenmesi: Uşak üniversitesi örneği. 9. Ulusal Fen ve Matematik Eğitimi Kongresi. Dokuz Eylül Üniversitesi, 23-25 Eylül, İzmir. İşman, A., Baytekin, Ç., Balkan, F., Horzum, M. B. ve Kıyıcı, M. (2002). Fen bilgisi eğitimi ve yapısalcı yaklaşım. The Turkish Online Journal of Educational Technology, 1(1), 41-47.

Kabapınar, Y. (2012). Kuramdan uygulamaya hayat bilgisi ve sosyal bilgiler öğretimi. Ankara: Pegem Akademi.

Karadağ, E., Deniz, S., Korkmaz, T. ve Deniz, G. (2008). Yapılandırmacı öğrenme yaklaşımı: sınıf öğretmenleri görüşleri kapsamında bir araştırma. Uludă̆ Üniversitesi Ĕ̆itim Fakültesi Dergisi, 21(2), 383-402.

Kasapoğlu, K. ve Duban, N. (2012). Sınıf öğretmeni adaylarının yapılandırmacı yaklaşımı uygulamaya yönelik öz yeterlik inançlarını yordayan bir faktör olarak yapılandırmacı yaklaşıma yönelik tutumları (Afyonkarahisar İli Örneği). Mersin Üniversitesi Eğitim Fakültesi Dergisi, 8(2), 85-96.

Lakoff, G. ve Johnson, M. (2005). Metaforlar hayat, anlam ve dil. (Çev. G.Y. Demir). İstanbul: Paradigma.

Miles, M. B. ve Huberman, A.M. (1994). An expand sourcebook: qualitative data analysis. USA: Sage Publication.

Murphy, E. (1997). Constructivism: From Philosophy to Practice. https://files.eric.ed.gov/fulltext/ED444966.pdf adresinden 24/02/2020 tarihinde alınmıştır

Özden, Y. (2010). Öğrenme ve ögrretme. Ankara: Pegem Yayıncılı.

Özdemir, Y. ve Kıroğlu, K. (2011). Sınıf öğretmenlerinin yapılandırmacı öğrenme kuramına ilişkin bilgi düzeyleri. Selçuk Üniversitesi Ahmet Keleşoğlu Eğitim Fakültesi Dergisi, 32, 265-283. 
YYÜ Eğitim Fakültesi Dergisi (YYU Journal of Education Faculty), 2021; 18(1)766-795, http://efdergi.yyu.edu.tr,

Özenç, M. ve Doğan, C. (2012). Sınıf öğretmenlerinin yapılandırmacı yaklaşım yeterlik düzeylerinin belirlenmesi. Abant İzet Baysal Üniversitesi Ĕgitim Fakültesi Dergisi, 12(1), 67-83.

Paavola, S. ve Lakkala, M. (2004) "What is good learning?" https://s3.amazonaws.com/academia.edu.documents/6172825/q1_1_long_answer_what is_good_learning.pdf adresinden 20/04/2020 tarihinde alınmıştır.

Perkins, D. (1999 ).The many faces of constructivism. Educational Leadership. 57, 3. 6- 11.

Reeves, T. C. Herrington, J.ve Oliver, R. (2002) “Authentic activities and online learning”. https://researchrepository.murdoch.edu.au/id/eprint/7034/1/authentic_activities_online HERDSA_2002.pdf adresinden 13/04/2020 tarihinde alınmıştır.

Saban, A. (2004). Giriş düzeyindeki sınıf öğretmeni adaylarının “öğretmen” kavramına ilişkin ileri sürdükleri metaforlar. Türk Eğitim Bilimleri Dergisi, 2(2), 131-155.

Saban, A. (2008). İlköğretim I. kademe öğretmen ve öğrencilerinin bilgi kavramına ilişkin sahip oldukları zihinsel imgeler. İlköğretim Online, 7(2), 421-455.

Saban, A. (2009). Öğretmen adaylarının öğrenci kavramına ilişkin sahip olduğu zihinsel imgeler. Türk Ĕ̆itim Bilimleri Dergisi, 7(2), 281-326.

Saban, A., Koçbekir, B. N. ve Saban, A. (2006). Öğretmen adaylarının öğretmen kavramına ilişkin algılarının metafor analizi yoluyla incelenmesi. Kuram ve Uygulamada Eğitim Bilimleri, 6(2), 461-522.

Savery, J. R. ve Duffy, T. M. (1995). Problem based learning: An instructional model and its constructivist framework. Educational Technology, 35(5), 31-38.

Saydam, G. (2009). Sinıf öğretmenlerinin yapılandırmacı öğretim uygulamalarına ilişkin görüş ve tutumları. Yayınlanmamış Yüksek Lisans Tezi, Sosyal Bilimler Enstitüsü, Adnan Menderes Üniversitesi, Aydın.

Semerci, Ç. (2007). Program geliştirme kavramına ilişkin metaforlarla yeni ilköğretim programlarına farklı bir bakış. Çukurova Üniversitesi Sosyal Bilimler Dergisi, 31(1), 139154.

Senemoğlu, N. (2005). Kuramdan uygulamaya gelişim öğrenme ve öğretim (12. Baskı). Ankara: Gazi Kitapevi.

Sercu, L., García, M. ve Prieto, P. C. (2005). Culture learning from a constructivist perspective. An investigation of Spanish foreign language teachers' views. Language and Education, 19(6), 483-495. 
YYÜ Eğitim Fakültesi Dergisi (YYU Journal of Education Faculty), 2021; 18(1)766-795, http://efdergi.yyu.edu.tr,

Sharkey, M. ve Gash, H. (2020). Teachers’ constructivist and ethical beliefs. Behavioral Sciences, 10(6), 96.

Sherman T. M. ve Kurshan, B. L. (2005). Constructing learning: Using technology to support teaching for understanding. Learning ve Leading with Technology, 32(5), 5-10.

Temli Durmuş, Y. (2014). 4. ve 5. sınıf öğretmenlerinin oluşturmacı yaklaşıma yönelik görüşleri. E-International Journal of Educational Research, 5(1).

Tezci, E. (2002). Oluşturmacı ögretim tasarım uygulamasının ilköğretim beşinci sınıf ögrencilerinin yaratıcılıklarına ve başarılarına etkisi. Yayınlanmamış Doktora Tezi, Sosyal Bilimler Enstitüsü, Fırat Üniversitesi, Elazı̆̆g.

Tezci, E. ve Gürol, A. (2003). Oluşturmacı öğretim tasarımı ve yaratıcılık. The Turkish Online Journal of Educational Technology 2(1), 50- 55.

Thomas, G. P. ve McRobbie, C. J. (2001). Using metaphor for learning to improve students’ metacognition in the chemistry classroom. Journal of Research in Science Teaching, 38, 222-259.

Tynjälä, P. (1999). Toward expert knowledge? A comparison between a constructivist and a traditional learning environment in the university. International Journal of Educational Research, 31(5), 357-442.

Von Glasersfeld, E. (1995). Radical constructivism: A way of knowing and learning. London: Falmer Pres.

Wang, L. ve Ha, A. S. (2012). Factors influencing pre-service teachers' perception of teaching games for understanding: A constructivist perspective. Sport, Education and Society, 17(2), 261-280.

Yang, F. Y., Chang, C. Y. ve Hsu, Y. S. (2008). Teacher views about constructivist instruction and personal epistemology: A national study in Taiwan. Educational Studies, 34(5), 527542.

Yager, R. (1991). The constructivist learning model, towards real reform in science education. The Science Teacher, 58(6), 52- 57.

Yaşar, Ş. (1998). Yapısalcı kuram ve öğrenme-öğretme süreci. Anadolu Üniversitesi Eğitim Fakültesi Dergisi, 8(1-2), 68-75.

Yıldırım, A. ve Şimşek, H. (2011). Sosyal bilimlerde nitel araştırma yöntemleri. Ankara: Seçkin Yayıncılık. 


\section{Summary}

\section{Statement of Problem}

Constructivist approach is a concept that has been discussed quite a lot in the literature of educational sciences recently. This is due to the fact that constructivism looks at the opposite of the objectivism and the behavioral approach to the acquisition of knowledge, the learning and teaching processes. According to the objectivist and behavioral approach, the objective information that exists in the external world, regardless of the learner, can be conveyed to individuals using the method of expression and appropriate reinforcers. Learning takes place when the learner puts this information in his mind or memorizes it. Tezci and Gürol (2003) state that knowledge is not independent of the learner in constructivist understanding. The individual who interacts with his/her environment creates individual information by making sense of the information he/she received from the outside world according to her previous knowledge, experiences and attitudes. Namely, according to constructivism approach, new learning takes place by associating the newly encountered information with the previous information and linking to known topics (Sherman, Barbara \& Kurshan, 2005).

In this study, the opinions of prospective primary school teachers about the constructivist approach were tried to be determined by means of metaphors. In the related body of literature, there is no study prospective primary school teachers' perceptions about the concept of constructivist approach were determined via metaphors. In this regard, the research is different from other studies in the body of literature. In addition to this, in the research, it is thought that academicians and field specialists working in the primary teacher training program will gain important perspectives with the determination of the perceptions of the primary teacher candidates about the constructivist approach and the categories in which they will be located. In this regard, the answers to the following questions are sought in the research:

Through which metaphors do prospective primary school teachers explain their perceptions about the concept of “constructivist approach”?

Regarding the concept of “constructivist approach”, what are the metaphors expressed by prospective primary school teachers, under which categories are they collected with regard to common features?

\section{Method}

In this study, the phenomenology, one of the qualitative research designs, was used. The study group of this research consists of 117 prospective primary school teachers who are 
studying in the 4th grade at Dicle and Marmara University primary school teaching department. The study group was determined with criterion sampling technique. In order to reveal the metaphors that the prospective primary school teachers participating in the research have about the concept of "constructivist approach", a form with phrases such as "constructivist approach is......" or "because....." is given and they were asked to write a single metaphor by focusing on their ideas about the concept of constructivist approach. The data obtained from this research were analyzed using “content analysis” technique.

\section{Findings, Result and Discussion}

It can be seen that the pre-service teachers of the constructivist approach produced a total of 80 valid metaphors and 96 opinions. Metaphors of "life" and "life itself" 5 times; The metaphors of "building a building", "child", "construction", "north star", "wood fire", "freedom", "life" and "jigsaw" have been expressed twice by class teachers. The remaining metaphors are produced by prospective primary school teachers once. Based on these data, it can be said that quite different and excessive metaphors are produced by the prospective primary school teachers regarding the constructivist approach.

It can be seen that the category which the prospective primary school teachers related to the constructivist approach produce the most metaphor is "activating the student” (f:28). This category is followed by those categories “creating meaningful information” (f:22), "relavance to life” (f:11), “expression of development” (f:9), “creativity and originality” (f:8), “focus on individual differences” (f:7). The categories, which the metaphors produced by the primary teacher candidates are classified at least, are "requiring implementation effort and labor” (f:4), "generation permanent information” (f:3), "requiring change and continuity” (f:3) and "Being guide and guiding” (f:2).

The second category in which the metaphors developed by the prospective primary school teachers are mostly classified is the "constructivist approach as a process of creating meaningful information”. It is seen that there are 22 metaphors under this category. In this regard, it is possible to say that an important part of the prospective primary school teachers who participated in the research evaluated constructivist learning as a process of creating meaningful information. According to constructivism, Özden (2010) states that the individual enters a construction process while creating the information. The individual makes sense of information individually or socially in this creating process. It can be said that the evaluation made by prospective primary school teachers coincides with the relevant literature. 
YYÜ Eğitim Fakültesi Dergisi (YYU Journal of Education Faculty), 2021; 18(1)766-795, http://efdergi.yyu.edu.tr,

According to the results obtained in the research, it can be seen that the prospective primary school teachers' perceptions of the constructivist approach are mostly related to the philosophy of constructivism and their perspective on the learning process. In addition, the contribution of constructivism to student development and the responsibilities it imposes on the teacher shape the perceptions of primary teachers' constructivist approach.

\section{Etik Kurul Kararı}

Dicle Üniversitesi Sosyal ve Beşeri Bilimler Etik Kurulu Başkanlığı'nın, 28/04/2020 tarih ve 43785 sayılı oluru gereği çalışma açısından Sosyal ve Beşeri Etik Kuralları ve İlkeleri çerçevesinde herhangi bir sakınca olmadığına karar verilmiştir. 